\title{
PENGARUH PENAMBAHAN LIMBAH KULIT KERANG BAMBU SEBAGAI PENGGANTI SEBAGIAN SEMEN TERHADAP NILAI KUAT LENTUR DAN POLA RETAK BALOK BETON BERTULANG DENGAN PENAMBAHAN ZAT KIMIA TIPE F (SUPERPLASTICIZER)
}

\author{
Taurina Jemmy Irwanto ${ }^{1}$ dan Yunita Ayunda Putri ${ }^{2}$ \\ ${ }^{I}$ Program Studi Teknik Sipil, Fakultas Teknik, Universitas Madura, Pamekasan \\ ${ }_{2}^{2}$ Program Studi Teknik Sipil, Fakultas Teknik, Universitas Madura, Pamekasan \\ E-mail: jirone@gmail.com, rn.yunitaayunda@gmail.com
}

\begin{abstract}
ABSTRAK: Kebutuhan yang meningkat akan beton menimbulkan berbagai inovasi dalam pemilihan material penyusunnya. Keberadaan kerang bambu atau yang lebih dikenal dengan istilah lorjuk (solen vaginalis), merupakan komoditas unggulan di Pulau Madura. Banyak penggunan hanya seputar dagingnya saja, tetapi kulitnya dibuang begitu saja. Maka dari itu untuk mengatasi limbah kulit kerang bambu tersebut, diperlukan adanya sebuah inovasi baru seperti dalam pembuatan beton yang mana kulit kerang bambu digunakan sebagai campuran bahan penyusunnya. Penelitian ini dilakukan untuk mengetahui pengaruh penambahan limbah kulit kerang bambu sebagai pengganti sebagian semen pada balok beton bertulang dengan dan tanpa penambahan zat kimia tipe $\mathrm{F}$ (superplasticizer). Tujuan dari penelitian ini ialah untuk mengetahui nilai kuat lentur dan pola retak pada balok beton bertulang dengan menambahkan zat additive pada campurannya, yang menggunakan sebanyak 4 sample dengan masing-masing variasi campuran $0 \%, 3 \%, 4 \%$, dan $5 \%$. Penelitian ini menggunakan metode pengujian $T$-test one sample, untuk menentukan nilai perbedaan dari hasil analisis dan hasil uji laboratorium yang membandingkan satu variabel bebas. Hasil dari penelitian ini nilai Pcr uji balok beton bertulang yang didapat adalah menerima $\mathrm{H}_{1}$ dan menolak $\mathrm{H}_{0}$ sehingga ada pengaruh penambahan serbuk kerang bambu terhadap beban yang mampu ditahan balok beton bertulang terhadap Pcr uji pada saat terjadi keruntuhan balok.
\end{abstract}

Kata kunci: Kulit kerang bambu, superplasticizier, pola retak.

\section{PENDAhUluan}

Beton merupakan suatu beban konstruksi suatu bahan konstruksi yang banyak digunakan pada pembangunan konstruksi saat ini karena beton banyak memiliki kelebihan jika dibandingkan dengan bahan lain, harganya relatif murah, mudah dikerjakan, dan dibentuk, bahan baku penyusun mudah di dapat, tahan lama, tahan api, dan tidak mengalami pembusukan. Bahan pembuatan beton di dapat dari pencampuran agregat halus dan kasar yaitu pasir dan kerikil, dengan menambahkan secukupnya bahan perekat semen dan air sebagai bahan pembantu guna keperluan reaksi kimia selama proses pengerasan dan perawatan beton secara langsung.

Secara Teknik, beton selalu dituntut untuk memenuhi tantangan akan kebutuhan bahan konstruksi, dimana beton yang dihasilkan biasanya diharapkan mempunyai kualitas dan daya tahan/kekuatan yang tinggi dengan mengabaikan nilai ekonomis dan lingkungannya. Nilai kekuatan serta daya tahan (durability) beton merupakan fungsi dari banyak faktor, diantaranya ialah nilai banding campuran dan mutu bahan penyusun, metode pengecoran, pelaksanaan finishing, temperatur beton, dan kondisi perawatan pengerasannya.

Kebutuhan yang meningkat akan beton menimbulkan berbagai inovasi dalam pemilihan material penyusunnya. Mengingat di Indonesia yang memiliki potensi sumberdaya hayati yang cukup tinggi yang dapat dimanfaatkan kembali. Menurut Sulistiono dkk. (2001), menyatakan bahwa luas wilayah perairan laut Indonesia diperkirakan mencapai 5,8 juta $\mathrm{km}^{2}$ dengan Panjang garis pantai $81.000 \mathrm{~km}^{2}$. Wilayah ini telah diketahui memiliki potensi sumberdaya hayati yang cukup tinggi, termasuk sumberdaya hayati perairan. Sumberdaya perairan termasuk sumberdaya yang dapat pulih kembali, namun demikian diperlukan usaha-usaha pengelolaan agar pengusahaan sumberdaya tersebut dapat berlangsung lestari.

Salah satu sumberdaya hayati perairan yaitu kerang bambu atau kerang pisau dengan nama latin solen vaginalis. Keberadaan kerang bambu atau yang lebih dikenal di Pulau Madura dengan istilah lorjuk (solen vaginalis), merupakan komoditas unggulan di Pulau Madura. Sejak dibuka aksesnya jembatan Suramadu, kebutuhan akan kerang ini semakin meningkat karena kerang ini merupakan bahan dasar dan tambahan bagi beberapa jenis makanan khas Madura seperti lorjuk goreng, rengginang lorjuk, kacang lorjuk, maupun campur lorjuk. Kebutuhan akan kerang pisau ini menyebabkan peningkatan penangkapan yang dilakukan oleh nelayan yang dekat dengan area keberadaan kerang bambu. Aktivitas penangkapan oleh nelayan yang berlebihan ini dan tanpa memperhatikan potensi melestarikan membuat keberadaannya terancam punah. Selain itu juga adanya aktifitas manusia dalam penambangan pasir laut yang merupakan habitat hidup kerang bambu tersebut serta menyebabkan kondisi habitat kerang bambu (solen vaginalis) untuk tumbuh dan berkembang biak akan mengalami tekanan dan keberadaan populasinya akan berkurang (Abida, 2003).

Karena banyaknya penggunaan kerang bambu ini, sehingga kulit kerang bambu itu sendiri semakin berlimpah dan hanya sebagian kecil yang memanfaatkan kulitnya untuk kerajinan dan sebagian besar lainnya dibuang begitu saja. Maka dari itu untuk mengatasi limbah kulit kerang bambu tersebut, diperlukan adanya sebuah inovasi baru seperti dalam pembuatan beton yang mana kulit kerang bambu digunakan sebagai campuran bahan penyusunnya. 


\section{METODOLOGI PENELITIAN}

Dalam penelitian ini dibutuhkan 12 buah benda uji pada usia beton 28 hari, yang semua benda uji perlakuannya dengan balok beton bertulang berukuran 150x150x60 mm dan mutu beton $25 \mathrm{Mpa}$, yang menggunakan campuran semen, pasir, dan kerikil dan menggunakan serbuk cangkang kerang bambu dengan variasi $0 \%, 3 \%, 4 \%$ dan $5 \%$ dengan jumlah benda uji sebanyak 3 buah pada setiap variasinya seperti yang dijelaskan pada Tabel 1 dan Tabel 2.

Tabel 1. Rancangan Benda Uji

\begin{tabular}{|c|c|c|c|}
\hline $\begin{array}{l}\text { Yariasi Penambahan serbuk } \\
\text { cangkang kerang bambu }\end{array}$ & $\begin{array}{c}\text { Jumlah } \\
\text { benda uji }\end{array}$ & $\begin{array}{l}\text { Penamaan } \\
\text { benda uji }\end{array}$ & $\begin{array}{c}\text { Umur Pengujian } \\
\text { (hari) }\end{array}$ \\
\hline \multirow{3}{*}{$0 \%$} & \multirow{3}{*}{3} & A1 & \multirow{12}{*}{28 hari } \\
\hline & & A2 & \\
\hline & & $\mathrm{A} 3$ & \\
\hline \multirow{3}{*}{$3 \%$} & \multirow{3}{*}{3} & B1 & \\
\hline & & B2 & \\
\hline & & B3 & \\
\hline \multirow{3}{*}{$4 \%$} & \multirow{3}{*}{3} & $\mathrm{C} 1$ & \\
\hline & & $\mathrm{C} 2$ & \\
\hline & & C3 & \\
\hline \multirow{3}{*}{$5 \%$} & \multirow{3}{*}{3} & D1 & \\
\hline & & D2 & \\
\hline & & D3 & \\
\hline Jumlah Keseluruhan & \multicolumn{3}{|c|}{12} \\
\hline
\end{tabular}

Tabel 2. Komposisi Kebutuhan Bahan Campuran Beton Untuk $1 \mathrm{M}^{3}$

\begin{tabular}{|c|c|c|c|c|c|c|c|}
\hline $\begin{array}{c}\text { Campuran } \\
\text { Beton }\end{array}$ & $\begin{array}{c}\text { Kebutuhan } \\
\text { Bahan }\end{array}$ & $\begin{array}{c}\text { Air } \\
\text { Liter) }\end{array}$ & $\begin{array}{c}\text { Semen } \\
(\mathbf{K g})\end{array}$ & $\begin{array}{c}\text { Pasir } \\
(\mathbf{K g})\end{array}$ & $\begin{array}{c}\text { Kerikil } \\
(\mathbf{K g})\end{array}$ & $\begin{array}{c}\text { Serbuk } \\
\text { Kerang } \\
\text { Bambu (Kg) }\end{array}$ & $\begin{array}{c}\text { Superplas- } \\
\text { ticizier }\end{array}$ \\
\hline \multirow{2}{*}{$f^{\prime}{ }^{\prime} 25 \mathrm{Mpa}$} & $1 \mathrm{~m}^{3}$ & 205 & 431.58 & 667.45 & 1043.97 & & \\
\cline { 2 - 8 } & 1 sampel & 3.04 & 6.4 & 9.9 & 15.50 & & \\
\cline { 2 - 8 } & 1 zak semen & 18.24 & 40.00 & 59.4 & 93 & & \\
\hline $\begin{array}{c}\text { Campuran serbuk } \\
\text { Kerang bambu }\end{array}$ & $3 \%$ & & & & & 0.25 & \\
\hline & $4 \%$ & & & & & 0.33 & \\
\hline & $5 \%$ & & & & & 0.41 & \\
\hline Superplasticizier & $\begin{array}{c}1 \% \text { dari } \\
\text { berat semen }\end{array}$ & & & & & & 4.3 \\
\hline
\end{tabular}

Berdasarkan Tabel 1 dan Tabel 2 maka dapat diketahui jumlah benda uji dan campurannya. Untuk rancangan penelitian adituangkan pada Gambar 1 bagan alir sebagai berikut:

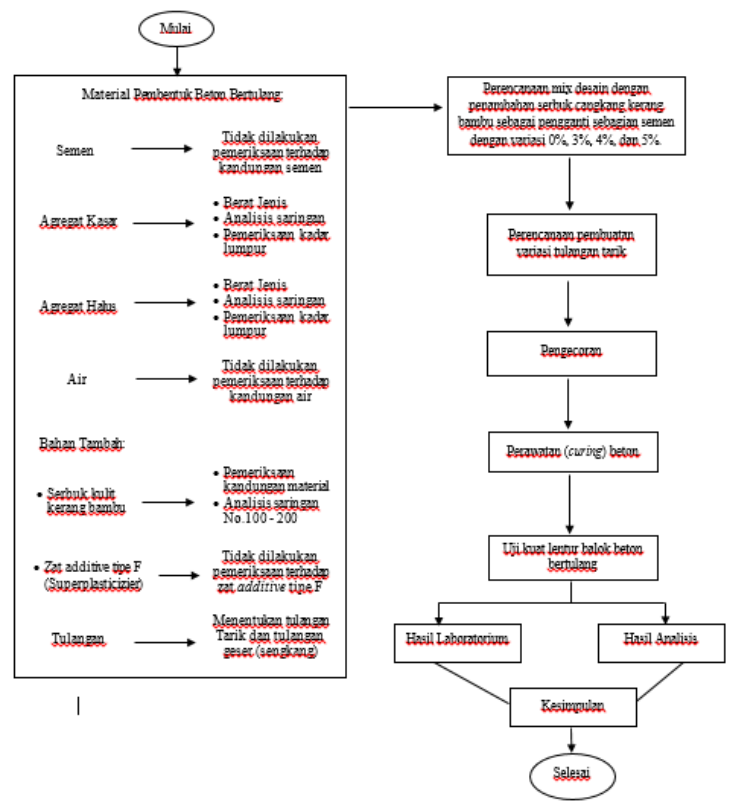

Gambar 3.1. Diagaram Alir penelitian

\section{HASIL PERHITUNGAN DAN ANALISA}

Dari hasil pengujian kuat tekan hancur beton didapat nilai seperti pada Tabel 3 berikut

Tabel 3. Kuat tekan hancur beton

\begin{tabular}{|c|c|c|c|c|c|}
\hline $\begin{array}{c}\text { Nomor } \\
\text { Benda Uji }\end{array}$ & $\begin{array}{c}\text { Prosentase serbuk } \\
\text { kerang bambu } \\
(\%)\end{array}$ & $\begin{array}{c}\text { Berat } \\
\text { Volume } \\
\left(\mathrm{kg} / \mathrm{m}^{3}\right)\end{array}$ & $\begin{array}{c}\text { Berat } \\
\text { Volume } \\
\text { Rata-rata } \\
\left(\mathrm{kg} / \mathrm{m}^{3}\right)\end{array}$ & $\begin{array}{c}f_{c}^{\prime} \\
\text { (Mpa) }\end{array}$ & $\begin{array}{c}f^{\prime}{ }_{C} \text { Rata-rata } \\
\text { (Mpa) }\end{array}$ \\
\hline A1 & 0 & 2345.7 & \multirow{3}{*}{2296.0} & 21.663 & \multirow{3}{*}{23.0} \\
\hline $\mathrm{A} 2$ & 0 & 2280.8 & & 22.626 & \\
\hline A3 & 0 & 2261.4 & & 24.741 & \\
\hline B1 & 3 & 2245.3 & \multirow{3}{*}{2358.1} & 21.791 & \multirow{3}{*}{22.9} \\
\hline B2 & 3 & 2463.4 & & 22.112 & \\
\hline B3 & 3 & 2365.5 & & 24.881 & \\
\hline $\mathrm{C} 1$ & 4 & 2365.2 & \multirow{3}{*}{2299.5} & 24.912 & \multirow{3}{*}{23.6} \\
\hline $\mathrm{C} 2$ & 4 & 2187.6 & & 23.615 & \\
\hline C3 & 4 & 2345.6 & & 22.225 & \\
\hline D1 & 5 & 2432.1 & \multirow{3}{*}{2378.3} & 21.825 & \multirow{3}{*}{22.3} \\
\hline D2 & 5 & 2243.2 & & 21.654 & \\
\hline D3 & 5 & 2459.6 & & 23.452 & \\
\hline
\end{tabular}

Dari hasil Tabel 3 maka kuat tekan rata-rata yang dihasilkan sebesar 23.0 Mpa sedangkan kuat tekan yang direncanakan adalah 25 Mpa. Sedangkan untuk hasil kapasitas lentur pada saat retak awal terdapat pada Tabel 4 dan Gambar 2 berikut.

Tabel 4. Kapasitas Lentur Pada Saat Retak Awal

\begin{tabular}{|c|c|c|c|c|c|c|}
\hline $\begin{array}{l}\text { Nomor } \\
\text { Balok }\end{array}$ & $\begin{array}{c}\text { Serbuk } \\
\text { kerang } \\
(\%)\end{array}$ & $\begin{array}{c}\text { Mcr } \\
\text { Analisis } \\
(\mathrm{kg} / \mathrm{cm})\end{array}$ & $\begin{array}{c}\text { Pcr } \\
\text { Analisis } \\
(\mathbf{k g})\end{array}$ & $\begin{array}{c}\text { Pcr Analisis } \\
\text { Rata-rata } \\
\text { (kg) }\end{array}$ & $\begin{array}{c}\text { Pcr Uji } \\
(\text { (kg) }\end{array}$ & $\begin{array}{c}\text { Pcr Uji } \\
\text { Rata-rata } \\
\text { (kg) }\end{array}$ \\
\hline A1 & \multirow{3}{*}{0} & 1515.495 & 433.856 & \multirow{3}{*}{477.309} & 387.492 & \multirow{3}{*}{322.91} \\
\hline A2 & & 1551.786 & 463.994 & & 254.929 & \\
\hline $\mathrm{A} 3$ & & 1633.479 & 534.077 & & 326.309 & \\
\hline B1 & \multirow{3}{*}{3} & 1519.548 & 437.587 & \multirow{3}{*}{474.94} & 387.492 & \multirow{3}{*}{428.28} \\
\hline B2 & & 1535.743 & 448.765 & & 458.872 & \\
\hline B3 & & 1637.639 & 538.467 & & 438.478 & \\
\hline $\mathrm{Cl}$ & \multirow{3}{*}{4} & 1614.896 & 531.65 & \multirow{3}{*}{494.19} & 356.901 & \multirow{3}{*}{398.68} \\
\hline $\mathrm{C} 2$ & & 1582.146 & 493.75 & & 458.872 & \\
\hline $\mathrm{C} 3$ & & 1556.577 & 457.18 & & 377.295 & \\
\hline D1 & \multirow{3}{*}{5} & 1520.622 & 438.579 & \multirow{3}{*}{456.04} & 356.901 & \multirow{3}{*}{302.52} \\
\hline D2 & & 1521.289 & 435.334 & & 275.323 & \\
\hline D3 & & 1594.605 & 494.203 & & 275.323 & \\
\hline
\end{tabular}

PERBANDINGAN PCR ANALISIS DAN PCR UJI

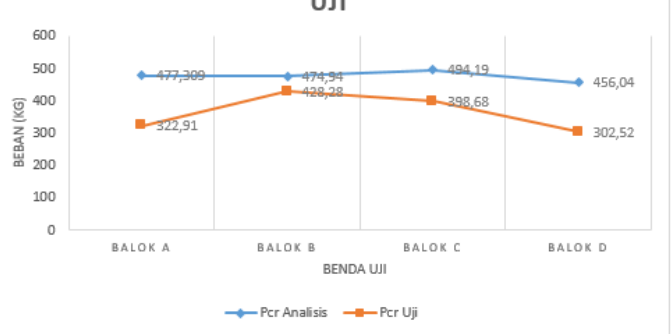

Gambar 2. Perbandingan grafik Pcr Analisa dan Pcr Uji

Pada Tabel 4 dan Gambar 2didapat beban retak awal pada balok A dari hasil analisis menghasilkan beban yang lebih tinggi daripada dengan Pcr Uji yaitu sebesar $477.309 \mathrm{~kg}$. Sedangkan untuk balok B kondisi retak awal terjadi pada beban $474.94 \mathrm{~kg}$, hasil ini kurang lebih sesuai dengan hasil penelitian yaitu sebesar $428.28 \mathrm{~kg}$. Begitu pula dengan balok $\mathrm{C}$ yang hasilnya kurang lebih sama dengan hasil penelitian yaitu sebesar $398.68 \mathrm{~kg}$. Pada balok D hasil analisa lebih tinggi dibandingkan dengan hasil penelitian yaitu sebesar $456.04 \mathrm{~kg}$. Secara garis besar, beban retak awal dari hasil analisa dan hasil 
penelitian relative sesuai, hanya saja pada balok $D$ mengalami penurunan sebesar $41 \%$ dari hasil analisis.

Perbandingan antara beban maksimum saat runtuh (Pn) dengan beban maksimum dari hasil pengujian $(\mathrm{Pu}$ uji) yang di bangkitkan oleh pompa hidraulik dapat di lihat pada tabel berikut yang juga memperlihatkan perbandingan momen ultimate hasil pengujian dan analisis perhitungannya. Dari nilai $\mathrm{Pu}$ uji pada saat runtuh tersebut didapat besarnya momen maksimum dari balok beton bertulang, yang kemudian hasil momen maksimum tersebut dibandingkan terhadap momen nominal dari balok dan dari hasil perbandingan momen tersebut bisa ditentukan jenis keruntuhan yang terjadi, selain dari hasil pengamatan pola retaknya. Seperti yang terlihat pada Gambar 3, Gambar 4, Gambar 5 dan Gambar 6 berikut:
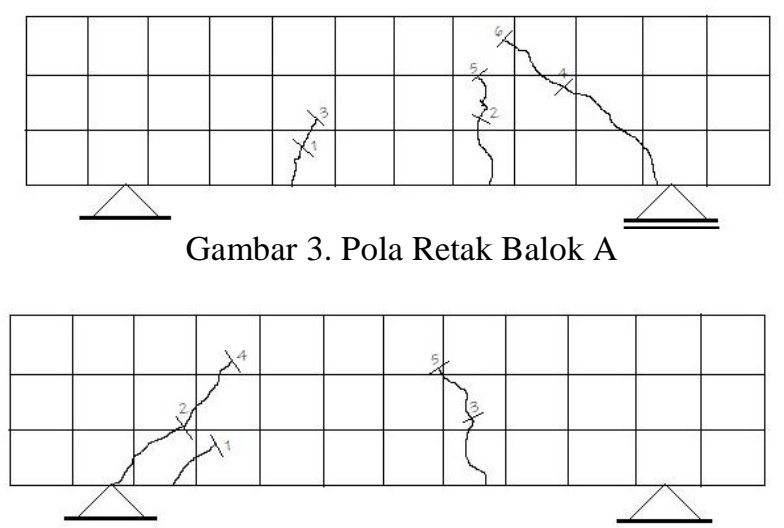

Gambar 4. Pola Retak Balok B

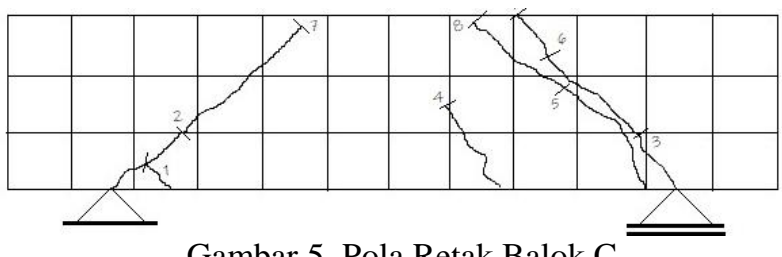

Gambar 5. Pola Retak Balok C

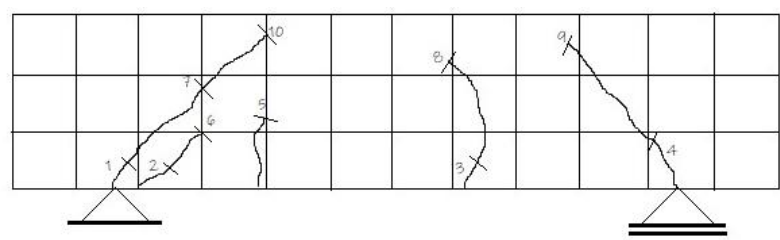

Gambar 6. Pola Retak Balok D

Berdasarkana Gambar 3 sampai Gambar 6 didapat variasi pola retak sedangkan nilai kapasitas lentur pada saat runtuh terdapat pada Tabel 5, perbandinagan momen saat runtuh terdapat pada Tabel 6 , dan jenis pola retak pada Tabel 7.

Tabel 5. Kapasitas Lentur Pada Saat Runtuh

\begin{tabular}{|c|c|c|c|c|c|}
\hline $\begin{array}{c}\text { Nomor } \\
\text { Balok }\end{array}$ & $\begin{array}{c}\text { Serbuk Kerang } \\
\text { (\%) }\end{array}$ & $\begin{array}{c}\text { Pu Analisis } \\
\text { (kg) }\end{array}$ & $\begin{array}{c}\text { Pu Analisis } \\
\text { rata-rata } \\
\text { (kg) }\end{array}$ & $\begin{array}{c}\text { Pu Uji } \\
\text { (kg) }\end{array}$ & $\begin{array}{c}\text { Pu uji } \\
\text { rata-rata } \\
\text { (kg) }\end{array}$ \\
\hline A1 & & 14675.6869 & & 9177.44 & \\
A2 & 0 & 15381.6863 & 15663.2 & 9687.3 & 9619.32 \\
A3 & & 16932.246 & & 9993.22 & \\
\hline B1 & & 14769.527 & & 9993.22 & \\
B2 & 3 & 15004.86 & 15603.1 & 9993.22 & 9891.25 \\
B3 & & 17034.883 & & 9687.3 & \\
\hline C1 & & 17057.61 & & 9075.47 & \\
C2 & 4 & 16106.747 & 16084.02 & 8361.67 & 8463.64 \\
C3 & & 15087.703 & & 7953.78 & \\
\hline D1 & & 14794.453 & & 9993.22 & \\
D2 & 5 & 14669.089 & 15150.26 & 9993.22 & 9585.33 \\
D3 & & 15987.248 & & 8769.56 & \\
\hline
\end{tabular}

Tabel 6. Perbandingan Momen Ultimate, Momen Nominal saat runtuh

\begin{tabular}{|c|c|c|c|c|c|c|c|}
\hline \begin{tabular}{c|} 
Nomor \\
Balok
\end{tabular} & $\begin{array}{c}\text { Serbuk } \\
\text { Kerang } \\
(\%)\end{array}$ & $\begin{array}{c}\text { Beban } \\
\text { runtuh } \\
(\mathrm{kg})\end{array}$ & $\begin{array}{c}\text { Reaksi } \\
\text { tumpuan }\end{array}$ & \begin{tabular}{|c|} 
Mu \\
$(\mathrm{kg} . \mathbf{m})$
\end{tabular} & \begin{tabular}{|c|} 
Mn \\
Teoritis \\
(kg.m)
\end{tabular} & $\frac{M u}{M n}$ & $\begin{array}{c}\text { Jenis } \\
\text { Keruntuhan }\end{array}$ \\
\hline A1 & & 9177.44 & 4588.72 & \begin{tabular}{|l|}
259.107 \\
\end{tabular} & 512.634 & 0.51 & Geser Tekan \\
\hline A2 & 0 & 9687.3 & 4843.65 & 277.541 & 514.426 & 0.54 & Geser Tekan \\
\hline A3 & & 9993.22 & 4996.61 & 312.299 & 517.874 & 0.60 & Geser Tekan \\
\hline B1 & & 9993.22 & 4996.61 & 330.305 & 512.881 & 0.64 & Geser tekan \\
\hline B2 & 3 & 9993.22 & 4996.61 & 321.791 & 513.489 & 0.63 & Geser tekan \\
\hline B3 & & 9687.3 & 4843.65 & 286.466 & 518.082 & 0.55 & Geser tekan \\
\hline $\mathrm{Cl}$ & & 8871.53 & 4435.77 & 219.504 & 518.13 & 0.42 & Geser Tekan \\
\hline $\mathrm{C} 2$ & 4 & 8667.59 & 4333.79 & 325.896 & 516.12 & 0.63 & Geser tekan \\
\hline $\mathrm{C} 3$ & & 9075.47 & 4537.74 & 306.96 & 513.70 & 0.59 & Geser Tekan \\
\hline D1 & & 8871.53 & 4435.77 & 298.356 & 512.945 & 0.58 & Geser Tekan \\
\hline D2 & 5 & 8871.53 & 4435.77 & 347.089 & 512.612 & 0.68 & Geser Tekan \\
\hline D3 & & 8769.56 & 4384.78 & 272.677 & 515.847 & 0.53 & Geser Tekan \\
\hline
\end{tabular}

Tabel 7. Jenis Keruntuhan Berdasarkan Pola Retak

\begin{tabular}{|c|c|c|}
\hline Nomor Balok & $\begin{array}{c}\text { Prosentase Serbuk } \\
\text { Kerang Bambu } \\
(\%)\end{array}$ & Jenis Keruntuhan \\
\hline $\mathrm{A} 1$ & \multirow{3}{*}{0} & Geser Tekan \\
\hline $\mathrm{A} 2$ & & Geser Tekan \\
\hline $\mathrm{A} 3$ & & Geser Tekan \\
\hline B1 & \multirow{3}{*}{3} & Geser tekan \\
\hline B2 & & Geser tekan \\
\hline B3 & & Geser Tekan \\
\hline $\mathrm{C} 1$ & \multirow{3}{*}{4} & Geser Tekan \\
\hline $\mathrm{C} 2$ & & Geser tekan \\
\hline $\mathrm{C} 3$ & & Geser Tekan \\
\hline D1 & \multirow{3}{*}{5} & Geser Tekan \\
\hline $\mathrm{D} 2$ & & Geser Tekan \\
\hline D3 & & Geser Tekan \\
\hline
\end{tabular}

Pada Tabel 5 sampai Tabel 7 didapat nilai pada balok A, B, C dan D terjadi keruntuhan geser tekan, dimana pola keretakannya terus merambat ke daerah tekan balok secara diagonal. Pada balok A dengan beban $90 \mathrm{kN}$, pola retak yang terjadi di daerah tumpuan sendi rol, dimana pola retaknya menunjukkan pola retak miring yang merambat secara diagonal kearah daerah tekan balok. Retak dan pola kehancuran yang terjadi pada balok ini diperlihatkan pada lampiran gambar pola retak balok beton uji di Balok A1.

\section{Pengujian Hipotesis}

Penyelesaian pada pengujian hipotesis ini menggunakan program Microsoft excel dengan hasil 
terdapat pada Tabel 7 sampai Tabel 9 serta pada Gambar 7 dengan hipotesis sebagai berikut .

$H_{0} \quad: t_{\text {hitung }} \leq t_{\text {tabel }}$ (tidak ada pengaruh penambahan serbuk kerang bambu terhadap beban yang mampu ditahan balok beton bertulang).

$H_{1}: t_{\text {hitung }}>t_{\text {tabel }}$ (ada pengaruh penambahan serbuk kerang bambu terhadap beban yang mampu ditahan oleh balok beton bertulang).

Menentukan significance level

$\alpha \quad$ : $\quad 10 \%$

Tabel 7. Hasil dari Pcr Analisa dan Pcr Uji

\begin{tabular}{|c|c|c|}
\hline Nomor Balok & Pcr Analisa & Pcr Uji \\
\hline A1 & 433.856 & 387.492 \\
\hline A2 & 463.994 & 254.929 \\
\hline A3 & 534.077 & 326.309 \\
\hline B1 & 437.587 & 387.492 \\
\hline B2 & 448.765 & 458.872 \\
\hline B3 & 538.467 & 438.478 \\
\hline C1 & 531.65 & 356.901 \\
\hline C2 & 493.75 & 458.872 \\
\hline C3 & 457.18 & 377.295 \\
\hline D1 & 438.579 & 356.901 \\
\hline D2 & 435.334 & 275.323 \\
\hline D3 & 494.203 & 275.323 \\
\hline
\end{tabular}

Tabel 8. Hasil Output Menguji Nilai T-1 test

\begin{tabular}{|c|c|c|}
\hline Hasil Output & Pcr Analisa & Pcr Uji \\
\hline average & 475.6201667 & 362.8489167 \\
\hline Satdev & 41.07916825 & 70.03770236 \\
\hline standart eror & 11.85853443 & 20.21814316 \\
\hline mean hypotesis & 400 & 400 \\
\hline Selisih & 75.62016667 & -37.15108333 \\
\hline $\begin{array}{c}\text { menghitung nilai T-hitung } \\
\text { nilai DF (degree of } \\
\text { freedom) }\end{array}$ & 6.376856023 & -1.837512132 \\
\hline $\begin{array}{c}\text { menghitung p value uji } \\
\text { student test 1 pihak (1 } \\
\text { tailed) }\end{array}$ & $2.62294 \mathrm{E}-05$ & 0.046636755 \\
\hline $\begin{array}{c}\text { menentukan t tabel uji 1 } \\
\text { pihak pada DF N-1 dan } \\
\text { probalitas atau alpha }\end{array}$ & 3.105806516 & 3.105806516 \\
\hline $\begin{array}{c}\text { menentukan hipotesis } \\
\text { diterima atau tidak }\end{array}$ & sig & no sig \\
\hline $\begin{array}{c}\text { menghitung P value uji } \\
\text { student test 2 pihak (2 } \\
\text { tailed) }\end{array}$ & $5.24588 \mathrm{E}-05$ & 0.09327351 \\
\hline
\end{tabular}

Tabel 9. Hasil Ouput Menguji nilai T-2 test

\begin{tabular}{|c|c|c|}
\hline Hasil Output & Pcr Analisa & Pcr Uji \\
\hline $\begin{array}{c}\text { menentukan t tabel uji 2 } \\
\text { pihak pada DF N-1 dan } \\
\text { probabilitas }\end{array}$ & 2.71807918 & 2.71807918 \\
\hline $\begin{array}{c}\text { menentukan batas } \\
\text { bawah daerah } \\
\text { penerimaan }\end{array}$ & 475.589109 & 362.817859 \\
\hline $\begin{array}{c}\text { menentukan batas atas } \\
\text { daerah penerimaan }\end{array}$ & 512.45048 & 425.642557 \\
\hline keputusan hipotesis uji 2 \\
pihak
\end{tabular}

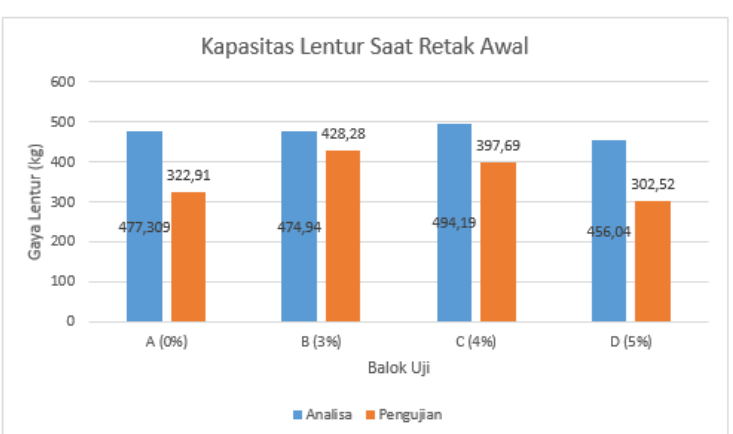

Gambar 7. Kapasitas Lentur Balok Beton Bertulang

Retak awal yang muncul setelah pembebanan dilakukan merupakan retak halus vertikal yang berupa retak lentur ditengah bentang dan daerah bawah beban. Dari Tabel 7 dan Gambar 2. Didapat Pcr analisa < Pcr uji itu menandakan retak geser lentur yang terjadi dari perambatan diagonal retak lentur.

Pada balok A dengan pencampuran serbuk kerang bambu sebesar 0\% menghasilkan Pcr uji sebesar $22 \%$. Pada balok B untuk Pcr uji mengalami kenaikan sebesar $30 \%$ dengan pencampuran serbuk kerang bambu sebesar $3 \%$. Pcr uji yang dihasilkan dari balok C sebesar $27 \%$ dengan pencampuran $4 \%$, dan pada balok D mengalami penurunan sebesar $6 \%$ dengan pencampuran $5 \%$ serbuk kerang bambu. Besarnya Pcr uji dari tiap-tiap tipe balok tersebut menunjukkan kemampuan menahan beban dari balok tersebut berbeda pula.

Dari hasil Output menggunakan Ms. Excel baik dari nilai T-1 Test dan T-2 test pada Tabel 8. dan Tabel 9. Berdasarkan hasil perhitungan analisa varian nilai Pcr uji balok beton bertulang maka hasil yang didapat adalah adalah $t_{\text {hitung }}>t_{\text {tabel }}$ hal ini menunjukkan menerima $H_{1}$ dan menolak $H_{0}$ yang artinya, ada pengaruh penambahan serbuk kerang bambu terhadap beban yang mampu ditahan balok beton bertulang terhadap Pcr uji pada saat terjadi keruntuhan balok.

\section{KESIMPULAN DAN SARAN KESIMPULAN}

Dari hasil penelitian dan pembahasan diatas dapat ditarik beberapa kesimpulan sebagai berikut:

1. Pada balok A dengan pencampuran serbuk kerang bambu sebesar 0\% menghasilkan Pcr uji sebesar 22\%. Pada balok B untuk Pcr uji mengalami kenaikan sebesar $30 \%$ dengan pencampuran serbuk kerang bambu sebesar 3\%. Pcr uji yang dihasilkan dari balok $\mathrm{C}$ sebesar $27 \%$ dengan pencampuran $4 \%$, dan pada balok D mengalami penurunan sebesar $6 \%$ dengan pencampuran 5\% serbuk kerang bambu.

2. Pada balok A, B, C dan D terjadi keruntuhan geser tekan. Dimana pola keretakannya terus merambat ke daerah tekan balok secara diagonal. Pada balok A dengan beban $90 \mathrm{kN}$, pola retak yang terjadi di daerah tumpuan sendi rol, dimana pola retaknya menunjukkan pola retak miring yang merambat secara diagonal kearah daerah tekan balok. Dimana retakan tersebut terjadi setelah retak lentur geser terjadi, retak merambat lebih jauh ke dalam daerah tekan dengan naiknya beban. Retak ini juga merambat sebagai suatu retak sekunder menuju 
tulangan tarik dan kemudian menerus secara horizontal sepanjang penulangan tersebut.

3. Berdasarkan hasil perhitungan analisa varian nilai Pcr uji balok beton bertulang maka hasil yang didapat adalah adalah $t_{\text {hitung }}>t_{\text {tabel }}$ hal ini menunjukkan menerima $H_{1}$ dan menolak $H_{0}$ yang artinya, ada pengaruh penambahan serbuk kerang bambu terhadap beban yang mampu ditahan balok beton bertulang terhadap Pcr uji pada saat terjadi keruntuhan balok.

\section{SARAN}

1. Perlu dilakukan penelitian lebih lanjut tentang pola retak pada balok beton bertulang dengan menambah variasi benda uji dengan jenis material serta penambahan zat additive yang berbeda.

2. Untuk mendapatkan hasil penelitian yang jauh lebih baik, sampel yang digunakan perlu lebih banyak lagi agar didapatkan data yang lebih bervariatif.

3. Penelitian ini juga dapat dikembangkan pada balok tinggi yaitu balok beton yang cenderung menahan pembebanan geser yang lebih dominan dibandingkan dengan beban lentur.

\section{DAFTAR PUSTAKA}

ASTM C 150: Standard Specification for Portland Cement.

Badan Standarisasi Nasional, 2002. Spesifikasi Agregat Ringan untuk Beton Ringan Struktural (SNI 022461-2002). Jakarta.

Badan Standarisasi Nasional, 2004. Semen Portland (SNI 15-2049-2004). Jakarta.

Dini, Restian. 2008. Analisis Pengaruh Dimensi Balok dan Kolom Portal Terhadap Lebar Retak Pada Bangunan. Laporan Skripsi. Jurusan Teknik Sipil Universitas Brawijaya Malang.

Departemen Pekerjaan Umum, 1989. Peraturan Beton Bertulang Indonesia, (PBI, 1971).

Dipohusodo, I,. 1994. Struktur Beton Bertulang, Penerbit Pustaka Utama. Jakarta.

Irwanto. J. Taurina, 2006. Pengaruh Penambahan Fly Ash Terhadap Pola Keruntuhan Balok Beton Bertulang Tanpa Tulangan Geser Beragregat Pumice (Batu Apung). Laporan Skripsi. Jurusan Teknik Sipil Universitas Brawijaya Malang.

SK SNI T-15-1991-03. Departemen Pekerjaan Umum R.I. Jakarta, 1991.

SNI 03-2847-2002. Tata Cara Perencanaan Struktur Beton untuk Bangunan. 
ISSN Cetak : $2527-5542$

ISSN Online : 2775 - 6017

Halaman ini sengaja dikosongkan 